\title{
Multivariate Statistical Research in Areas of the Cast Hyper-Eutectoid Steel Roll Manufacturing, in the Melting and Alloying Processing Stages
}

\section{Imre Kiss}

University Politehnica Timişoara, Faculty of Engineering Hunedoara, Department of Engineering \& Management, 5, Revolutiei, Hunedoara, Romania e-mail: imre.kiss@fih.upt.ro

Abstract: This study presents several key aspects of Adamite hyper-eutectoid steel roll manufacturing. Using the multivariate statistical research used as modelling approach upon the industrial data (roll's foundry and rolling sectors), the combined behavior of several chemical elements (graphitizing forming elements, Nickel $\mid$ Ni $\mid$ and Silicon $\mid$ Si $\mid$ ), and carbure forming elements, Manganese $|\mathrm{Mn}|$ and Chrome $|\mathrm{Cr}|$, under the presence of the Carbon $|C|$ ) upon the roll's hardness are presented. In this sense, several results of a complex study on the Adamite hyper-eutectoid steel rolls are presented. For generating the multiple regression equations, determination of the specific correlation coefficients and drawing the graphical addenda, the software Matlab was used.

Keywords: hyper-eutectoid steels; Adamite type rolls; graphitizing forming elements; carbide forming elements; hardness; multivariate regression analysis; correlation charts

\section{Introduction}

Prediction of the exploitation properties of rolls, based on the melting and alloying process of the alloys, is a prerequisite for the cast roll's manufacturing [1-8]. The statistical modelling by multivariate regression analysis can be used successfully to optimize the chemical composition during the rolls manufacturing process. In this way, this method is very helpful to predict the cast roll's performance [1-8].

We reported several studies [1-8], on mathematical modelling of cast rolls. In all the above studies, the combined effect of basic chemical composition in addition to the proper alloying elements has been considered separate or simultaneously, in case of the cast iron rolls [1-8]. Most of the studies reviewed above worked on modelling of cast iron rolls and their technological components which assure the proper hardness by the chemical composition variation, but not reviewed the cast steel-base rolls $[1-6,8]$. In the last 20 years, a general model for cast iron rolls is 
developed by the author, which can be applied now, in new research series, to the hyper-eutectoid steel rolls too [1,7]. The current analysis is based on the concept that is proven in several scientific works that the proper quality of a particular type of alloys (such as these hyper-eutectoid steels) and their properties are determined by chemical composition and a proper melting and alloying processing [1-8].

The current work is focused on the control of structure of hyper-eutectoid steels destined to the Adamite type rolls (Figure 1), in a perfect control of the melting and alloying processes which assure the cast roll's high exploiting properties, such as hardness. Of course, it's well known that the properties of cast rolls are also determined by microstructure, generated during the alloys solidification in the roll's casting molds and under the influence of applied rate of cooling [9-16]. Also, these rolls cannot be used in an as cast condition [7, 9-24]. The exploitation characteristics also depends on the heat treatment process (annealing, followed by tempering), which determine the microstructure [7, 17-24].

(a)
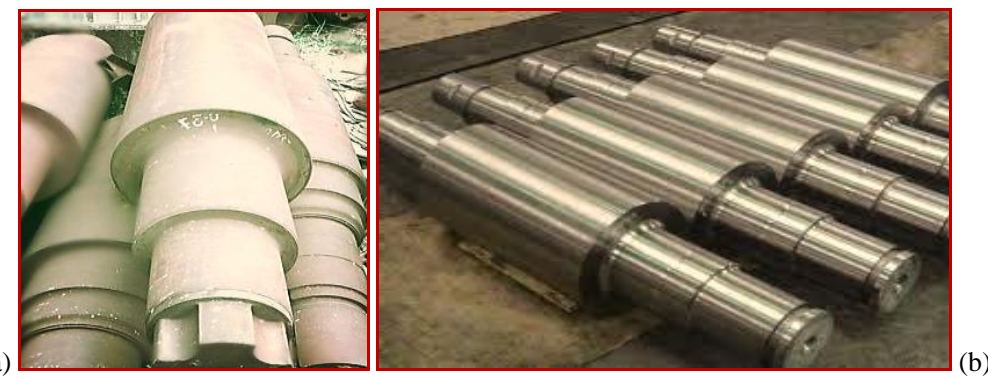

(c)
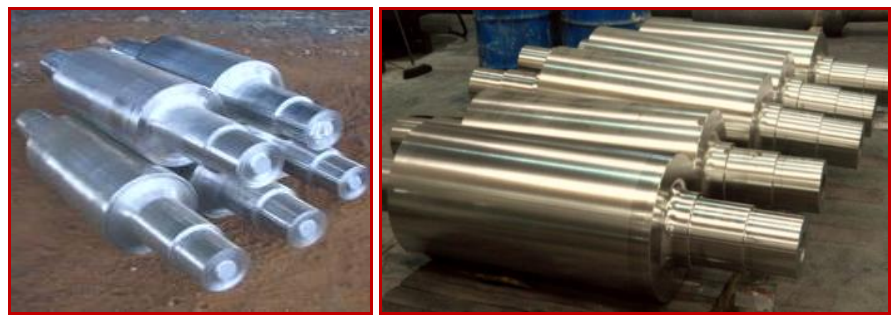

(b)

Figure 1

The Adamite type rolls (hyper-eutectoid steel rolls)

(a) rough cast hyper-eutectoid steel rolls; (b) processed cast hyper-eutectoid steel rolls, prepared for the heat treatment process (annealing, followed by tempering); (c) heat-treated cast hyper-eutectoid steel rolls; (d) hyper-eutectoid steel rolls, finally prepared for the rolling stands

A proper leading of the steel's melting and alloying conduct to high-quality steels, destined to become Adamite type rolls [7, 19]. In the melting of the steel's destined to Adamite rolls, the proper mechanical properties are adjusted, basically, through the quality of the used metallic charge, which requires extremely careful selection of metallic stock and a very closely controlled melting conditions (charging periods, temperatures regimes and variations, and operational times). 
Also, a rigid control of the chemical composition (primarily melting stage, alloying stages, corrections) is needed to obtain the required properties of the steel's meant for Adamite rolls [7, 17-24].

The alloying elements addition (Nickel $|\mathrm{Ni}|$, Chrome $|\mathrm{Cr}|$ and Molybdenum $|\mathrm{Mo}|$ ) and their proper correlation with the basic elements (Carbon $|\mathrm{C}|$, Silicon $|\mathrm{Si}|$ and Manganese $|\mathrm{Mn}|)$, is important too [1-9, 12, 15-18, 21]. In this sense, the main chemical composition (Table 1, Table 2) must be correlated with the addition of alloying elements, respecting the adequate proportions prescribed by the standards, besides an optimal ratio of the basic elements [1-9, 12, 15-18, 21]. Also, an optimal balance between the carbide forming elements in these steels (Manganese and Chrome $|\mathrm{Cr}|$ ) and the graphitizing forming elements (Silicon $|\mathrm{Si}|$ and Nickel $|\mathrm{Ni}|$, which decrease the stability of carbides) is very important for assure the roll's mechanical properties (Table 1, Table 2) [8, 15-18, 21-24]. All these, together with the provision of Carbon $|\mathrm{C}|$ requirements, ranging usually between 1.2-2.3\% (Table 1, Table 2) [8, 15-18, 21].

Adamite hyper-eutectoid steel rolls are stronger than cast iron rolls and harder than other steel rolls [7, 12, 15-18, 21-24]. The cast hyper-eutectoid steel roll's prominent feature is the small variation in hardness of the working surface, ranging from 40 to 55 degrees Shore C (300-420 HB) [7, 10, 14]. An outstanding feature of Adamite hyper-eutectoid steel rolls in that the inner hardness is about the same as that of the surface (Table 1, Table 2). Usually named Adamite type rolls, the cast hyper-eutectoid steel rolls (basically alloy steel rolls) contain Carbon $|\mathrm{C}|$ percentage ranging usually between 1.2-2.3\%, along-with several alloy elements such as Chrome $|\mathrm{Cr}|$, Nickel |Ni|, Molybdenum |Mo| and/or other alloy elements $[7,10,14]$. The extra Carbon $|C|$ value of this kind of high carbon steels, alongside with the special alloying element's percentage (Table 1, Table 2) and well-determined ratio provide an extra wear resistance and strength in exploitation $[7,14,18,21-24]$.

The proper values of the chemical composition of hyper-eutectoid steel rolls are found in the correlation diagrams presented in [7]. According to them (Table 1, Table 2), the proper concentration of each chemical element can be noticed, values that can assure the adequate hardness of these rolls [1-8].

Adamite hyper-eutectoid steel rolls are composed mainly of pearlite with some cementite in their structure [7, 9-24]. In fact, their structure contains dispersed carbides in a pearlitic matrix complementing the hardness and wear resistance imparted by highly alloyed matrix [7, 9-24]. Therefore, the proper mechanical characteristics of the Adamite rolls are obtained by the proper melting and alloying processes, by changing, on one side, the chemical balance between basic and alloying element, and on the other side, the structural balance between the carbide and the graphitizing forming elements in these steels, which are achieved by a close control of chemistry and process parameters. 
Table 1

Typical chemical compositions and hardness classes for Adamite hyper-eutectoid steel rolls

\begin{tabular}{|l|l|l|l|l|l|}
\hline $\begin{array}{l}\text { Hardness, } \\
|\mathrm{HB}|\end{array}$ & $\begin{array}{l}\text { Carbon, } \\
|\mathrm{C}|\end{array}$ & $\begin{array}{l}\text { Manganese, } \\
|\mathrm{Mn}|\end{array}$ & $\begin{array}{l}\text { Silicon, } \\
|\mathrm{Si}|\end{array}$ & $\begin{array}{l}\text { Nickel, } \\
|\mathrm{Ni}|\end{array}$ & $\begin{array}{l}\text { Chrome, } \\
|\mathrm{Cr}|\end{array}$ \\
\hline $300-340$ & $1.20-1.40$ & $0.60-0.90$ & $0.30-0.60$ & $0.60-\max$ & $0.80-1.00$ \\
\hline $340-370$ & $1.40-1.60$ & $0.60-0.90$ & $0.30-0.60$ & $0.60-\max$ & $1.00-1.20$ \\
\hline $370-420$ & $1.50-1.90$ & $0.60-0.90$ & $0.30-0.60$ & $0.80-1.40$ & $1.10-1.30$ \\
\hline
\end{tabular}

Table 2

Proposed chemical compositions for Adamite hyper-eutectoid steel rolls [7]

\begin{tabular}{|l|l|l|l|l|l|}
\hline $\begin{array}{l}\text { Hardness, } \\
|\mathrm{HB}|\end{array}$ & $\begin{array}{l}\text { Carbon, } \\
|\mathrm{C}|\end{array}$ & $\begin{array}{l}\text { Manganese, } \\
|\mathrm{Mn}|\end{array}$ & $\begin{array}{l}\text { Silicon, } \\
|\mathrm{Si}|\end{array}$ & $\begin{array}{l}\text { Nickel, } \\
|\mathrm{Ni}|\end{array}$ & $\begin{array}{l}\text { Chrome, } \\
|\mathrm{Cr}|\end{array}$ \\
\hline $300-420$ & $1.70-1.80$ & $0.65-0.85$ & $0.58-0.64$ & $1.30-1.50$ & $1.15-1.30$ \\
\hline
\end{tabular}

In case of the cast hyper-eutectoid steel rolls, the hardness highly depends on the degree of alloying elements and their balance and ratio, in relation to the basic elements, the chemical composition of this alloy being an important parameter which assures the structure, as a factor that determines the roll's basic physicmechanical properties $[7,8]$.

\section{Research Methodology}

The analyses follow the cumulative influences of several chemical components of the hyper-eutectoid steel, upon the hardness [7]. Results of the multivariate regression analysis, using Matlab, a number of multi-component regression equations, based on pertinent boundary conditions imposed by the standards are revealed $[1,7]$. Also, several regression surfaces are generated, which determine specific level curves that can be considered as correlation charts [7].

The first performed research had in view to obtain correlations between the hardness (defined by Hardness $|\mathrm{HB}|$ ) of the Adamite steel rolls and the graphitizing forming elements, (defined by one of the main basic element Silicon $|\mathrm{Si}|$ and one of the main alloying element - Nickel $|\mathrm{Ni}|)$, under the presence of the Carbon $|\mathrm{C}|$. The hyper-eutectoid steel's chemical composition and the resulted roll's hardness variation limits and their average values are presented in Table 3 (series 1: $|\mathrm{HB}|=\mathrm{f}\{|\mathrm{C}|,|\mathrm{Si}|,|\mathrm{Ni}|\}$ ).

The second research sought to obtain correlations between the hardness (defined by Hardness $|\mathrm{HB}|$ ) and the carbide forming elements (defined by another basic element - Manganese $|\mathrm{Mn}|$, and another alloying element - Chrome $|\mathrm{Cr}|)$, in the presence of the Carbon $|\mathrm{C}|$. Both studies generated a number of multi-component regression equations and correlation coefficients, determined to the $3^{\text {rd }}$ and $4^{\text {th }}$ 
dimensions spaces and also generated several regression surfaces and correlative level curves. For the multiple regression equations and the graphical addenda, the Matlab software was used [1-8].

The chemical composition and the hardness variation limits and their average values are presented in Table 4 (series 2: $|\mathrm{HB}|=\mathrm{f}\{|\mathrm{C}|,|\mathrm{Mn}|,|\mathrm{Cr}|\})$.

Table 3

The Adamite hyper-eutectoid steel rolls chemical composition and the hardness variation limits and their average values (series $1:|\mathrm{HB}|=\mathrm{f}\{|\mathrm{C}|,|\mathrm{Si}|,|\mathrm{Ni}|\}$ )

\begin{tabular}{|l|l|l|l|l|l|l|l|}
\hline \multicolumn{2}{|l|}{ Carbon, $|\mathrm{C}|$} & \multicolumn{2}{l|}{ Silicon, $|\mathrm{Si}|$} & \multicolumn{2}{l|}{ Nickel, $|\mathrm{Ni}|$} & \multicolumn{2}{l|}{ Hardness, $|\mathrm{HB}|$} \\
\hline $\begin{array}{l}|\mathrm{C}| \\
\min \end{array}$ & $\begin{array}{l}|\mathrm{C}| \\
\max \end{array}$ & $\begin{array}{l}|\mathrm{Si}| \\
\min \end{array}$ & $\begin{array}{l}|\mathrm{Si}| \\
\max \end{array}$ & $\begin{array}{l}|\mathrm{Ni}| \\
\min \end{array}$ & $\begin{array}{l}|\mathrm{Ni}| \\
\max \end{array}$ & $\begin{array}{l}|\mathrm{HB}| \\
\min \end{array}$ & $\begin{array}{l}|\mathrm{HB}| \\
\max \end{array}$ \\
\hline 1.52 & 2.02 & 0.54 & 0.72 & 1.17 & 1.66 & 311 & 412 \\
\hline$|\mathrm{C}|$ & & $|\mathrm{Si}|$ & $|\mathrm{Ni}|$ & & $|\mathrm{HB}|$ & \\
med & med & med & & med & \\
\hline 1.73 & 0.62 & 1.31 & 356 & \\
\hline
\end{tabular}

Table 4

The Adamite hyper-eutectoid steel rolls chemical composition and the hardness variation limits and their average values (series 2: $|\mathrm{HB}|=\mathrm{f}\{|\mathrm{C}|,|\mathrm{Mn}|,|\mathrm{Cr}|\}$ )

\begin{tabular}{|l|l|l|l|l|l|l|l|}
\hline \multicolumn{2}{|l|}{ Carbon, $|\mathrm{C}|$} & \multicolumn{2}{|l|}{ Manganese, $|\mathrm{Mn}|$} & \multicolumn{2}{l|}{ Chrome, $|\mathrm{Cr}|$} & \multicolumn{2}{l|}{ Hardness, $|\mathrm{HB}|$} \\
\hline $\begin{array}{l}|\mathrm{C}| \\
\min \end{array}$ & $\begin{array}{l}|\mathrm{C}| \\
\max \end{array}$ & $\begin{array}{l}|\mathrm{Mn}| \\
\min \end{array}$ & $\begin{array}{l}|\mathrm{Mn}| \\
\max \end{array}$ & $\begin{array}{l}|\mathrm{Cr}| \\
\min \end{array}$ & $\begin{array}{l}|\mathrm{Cr}| \\
\max \end{array}$ & $\begin{array}{l}|\mathrm{HB}| \\
\min \end{array}$ & $\begin{array}{l}|\mathrm{HB}| \\
\max \end{array}$ \\
\hline 1.52 & 2.02 & 0.60 & 0.92 & 1.04 & 1.37 & 311 & 412 \\
\hline $\begin{array}{l}|\mathrm{C}| \\
\text { med }\end{array}$ & $\begin{array}{l}|\mathrm{Mn}| \\
\text { med }\end{array}$ & $\begin{array}{l}|\mathrm{Cr}| \\
\text { med }\end{array}$ & $\begin{array}{l}|\mathrm{HB}| \\
\text { med }\end{array}$ \\
\hline 1.73 & 0.76 & 1.22 & 356 \\
\hline
\end{tabular}

\section{Statistical Modeling: Series 1}

In the case of series 1, where the correlations between the hardness of the Adamite hyper-eutectoid steel rolls and the graphitizing forming elements are studied (|HB| $=\mathrm{f}\{|\mathrm{C}|,|\mathrm{Si}|,|\mathrm{Ni}|\})$, using the values presented in Table 3 . An polynomial type of correlation was revealed, which have the following general form, presented in the equation (1).

$$
|H B|=a_{1} x^{2}+a_{2} y^{2}+a_{3} z^{2}+a_{4} x y+a_{5} x z+a_{6} y z+a_{7} x+a_{8} y+a_{9} z+a_{10}
$$

The proper mathematical correlation, in the case of series $1(|\mathrm{HB}|=\mathrm{f}\{|\mathrm{C}|,|\mathrm{Si}|$, $|\mathrm{Ni}|\}$ ), is given by the equation (2), where the correlation coefficient is $\mathrm{R}^{2}=$ 0.9240 . 


$$
\begin{aligned}
& |\mathrm{HB}|=\mathrm{a}_{1}|\mathrm{C}|^{2}+\mathrm{a}_{2}|\mathrm{Si}|^{2}+\mathrm{a}_{3}|\mathrm{Ni}|^{2}+\mathrm{a}_{4}|\mathrm{C}||\mathrm{Si}|+\mathrm{a}_{5}|\mathrm{Si}||\mathrm{Ni}|+\mathrm{a}_{6}|\mathrm{Ni}||\mathrm{C}|+\mathrm{a}_{7}|\mathrm{C}|+ \\
& \mathrm{a}_{8}|\mathrm{Si}|+\mathrm{a}_{9}|\mathrm{Ni}|+\mathrm{a}_{10}
\end{aligned}
$$

The polynomial coefficients of the governing equation (2) have the following statistically determined values:

- Second-degree terms coefficients are: $\mathrm{a}_{1}=60.1037 ; \mathrm{a}_{2}=-298.1222$ and $\mathrm{a}_{3}=-$ 118.6555

- Product terms coefficients are: $\mathrm{a}_{4}=-389.6696 ; \mathrm{a}_{5}=-208.5696$ and $\mathrm{a}_{6}=$ 390.1605

- First-degree terms coefficients are: $\mathrm{a}_{7}=442.7717 ; \mathrm{a}_{8}=541.1357$ and $\mathrm{a}_{9}=$ 524.9003

- Constant term is: $\mathrm{a}_{10}=-717.1688$

The $4^{\text {th }}$ dimensional regression surface, described by the governing equation (1) cannot be represented graphically [1-8]. Therefore, the independent variables were successively replaced with their average values (i.e. $|\mathrm{C}|$ med, $|\mathrm{Si}|$ med and $|\mathrm{Ni}|$ med, Table 1). A polynomial type of correlations was revealed, which have the following general forms, presented in the equations (3), (5) and (7).

In the case of series $1(|\mathrm{HB}|=\mathrm{f}\{|\mathrm{C}|,|\mathrm{Si}|,|\mathrm{Ni}|\})$, the equations (4), (6) and (8) were obtained, which can be represented graphically using the $3^{\text {th }}$ dimensions. The correlation coefficients are $\mathrm{R}^{2}$ at $|\mathrm{C}|$ med $=0.8108, \mathrm{R}^{2}$ at $|\mathrm{Si}| \mathrm{med}=0.9219$ and $\mathrm{R}^{2}$ at $|\mathrm{Ni}|$ med $=0.8969$.

$$
\begin{aligned}
& |\mathrm{HB}|=\mathrm{b}_{1} \mathrm{y}^{2}+\mathrm{b}_{2} \mathrm{z}^{2}+\mathrm{b}_{3} \mathrm{yz}+\mathrm{b}_{4} \mathrm{y}+\mathrm{b}_{5} \mathrm{z}+\mathrm{b}_{6} \\
& |\mathrm{HB}| \text { at }|\mathrm{C}|_{\text {med }}=\mathrm{b}_{1}|\mathrm{Si}|^{2}+\mathrm{b}_{2}|\mathrm{Ni}|^{2}+\mathrm{b}_{3}|\mathrm{Si}||\mathrm{Ni}|+\mathrm{b}_{4}|\mathrm{Si}|+\mathrm{b}_{5}|\mathrm{Ni}|+\mathrm{b}_{6}
\end{aligned}
$$

where the correlation coefficient is $\mathrm{R}^{2}$ at $|\mathrm{C}|_{\text {med }}=0.8108$

In the equation (4), the polynomial coefficients have the following values:

- Second-degree terms coefficients are: $b_{1}=-298.1222$ and $b_{2}=-118.6555$

— Product term coefficient is: $b_{3}=390.1605$

- First-degree terms coefficients are: $b_{4}=-134.8762$ and $b_{5}=163.0667$

- Constant term is: $\mathrm{b}_{6}=231.8572$

$$
\begin{aligned}
& |\mathrm{HB}|=\mathrm{c}_{1} \mathrm{X}^{2}+\mathrm{c}_{2} \mathrm{Z}^{2}+\mathrm{c}_{3} \mathrm{Xz}+\mathrm{c}_{4} \mathrm{X}+\mathrm{c}_{5} \mathrm{Z}+\mathrm{c}_{6} \\
& |\mathrm{HB}| \text { at }|\mathrm{Si}|_{\text {med }}=\mathrm{c}_{1}|\mathrm{C}|^{2}+\mathrm{c}_{2}|\mathrm{Ni}|^{2}+\mathrm{c}_{3}|\mathrm{C}||\mathrm{Ni}|+\mathrm{c}_{4}|\mathrm{C}|+\mathrm{c}_{5}|\mathrm{Ni}|+\mathrm{c}_{6}
\end{aligned}
$$

where the correlation coefficient is $\mathrm{R}^{2}$ at $|\mathrm{Si}|_{\text {med }}=0.9219$. 
In the equation (6), the polynomial coefficients have the following values:

- Second-degree terms coefficients are: $c_{1}=60.1037$ and $c_{2}=-118.6555$;

- Product term coefficient is: $c_{3}=-208.5696$

- First-degree terms coefficients are: $c_{4}=200.9167$ and $c_{5}=767.0598$

- Constant term is: $\mathrm{c}_{6}=-496.1487$

$$
|H B|=d_{1} x^{2}+d_{2} y^{2}+d_{3} x y+d_{4} x+d_{5} y+d_{6}
$$

$$
|\mathrm{HB}| \text { at }|\mathrm{Ni}|_{\text {med }}=\mathrm{d}_{1}|\mathrm{C}|^{2}+\mathrm{d}_{2}|\mathrm{Si}|^{2}+\mathrm{d}_{3}|\mathrm{C}||\mathrm{Si}|+\mathrm{d}_{4}|\mathrm{C}|+\mathrm{d}_{5}|\mathrm{Si}|+\mathrm{d}_{6}
$$

where the correlation coefficient is $\mathrm{R}^{2}$ at $|\mathrm{Ni}|_{\text {med }}=0.8969$.

In the equation (8), the polynomial coefficients have the following values:

- Second-degree terms coefficients are: $d_{1}=60.1037$ and $d_{2}=-298.1222$

- Product term coefficient is: $\mathrm{d}_{3}=-389.6696$

- First-degree terms coefficients are: $\mathrm{d}_{4}=170.5884$ and $\mathrm{d}_{5}=1050.2952$

- Constant term is: $\mathrm{d}_{6}=-234.2474$

\section{Statistical Modeling: Series 2}

In the case of series 2, where the correlations between the hardness of the Adamite hyper-eutectoid steel rolls and the carbide forming elements are studied $(|\mathrm{HB}|=$ $\mathrm{f}\{|\mathrm{C}|,|\mathrm{Mn}|,|\mathrm{Cr}|\})$, using the values presented in Table 4. A polynomial type of correlation was revealed, which have the same general form, presented above, in the equation (3).

The proper mathematical correlation, in the case of series $2(|\mathrm{HB}|=\mathrm{f}\{|\mathrm{C}|,|\mathrm{Mn}|$, $|\mathrm{Cr}|\}$ ), is given by the equation (9), where the correlation coefficient is $\mathrm{R}^{2}=$ 0.9508 .

$$
\begin{aligned}
& |\mathrm{HB}|=\mathrm{a}_{1}|\mathrm{C}|^{2}+\mathrm{a}_{2}|\mathrm{Mn}|^{2}+\mathrm{a}_{3}|\mathrm{Cr}|^{2}+\mathrm{a}_{4}|\mathrm{C}||\mathrm{Mn}|+\mathrm{a}_{5}|\mathrm{C}||\mathrm{Cr}|+\mathrm{a}_{6}|\mathrm{Mn}||\mathrm{Cr}|+ \\
& \mathrm{a}_{7}|\mathrm{C}|+\mathrm{a}_{8}|\mathrm{Mn}|+\mathrm{a}_{9}|\mathrm{Cr}|+\mathrm{a}_{10}
\end{aligned}
$$

The polynomial coefficients of the governing equation (9) have the following statistically determined values:

- Second-degree terms coefficients are: $\mathrm{a}_{1}=416.3963 ; \mathrm{a}_{2}=616.5716$ and $\mathrm{a}_{3}=$ 371.8899

- Product terms coefficients are: $\mathrm{a}_{4}=-573.5280 ; \mathrm{a}_{5}=504.0918$ and $\mathrm{a}_{6}=$ 309.2321 
- First-degree terms coefficients are: $\mathrm{a}_{7}=-1530.2369 ; \mathrm{a}_{8}=-294.7118$ and $\mathrm{a}_{9}=$ $-2141.0753$

- Constant term is: $\mathrm{a}_{10}=3084.8908$

Because the $4^{\text {th }}$ dimensional regression surface, described by the governing equation (9) cannot be represented graphically. Therefore, similar to the previous modeling series, the independent variables were successively replaced with their average values (i.e. $|\mathrm{C}| \mathrm{med},|\mathrm{Mn}| \mathrm{med}$ and $|\mathrm{Cr}| \mathrm{med}$, Table 2).

In the case of series $2(|\mathrm{HB}|=\mathrm{f}\{|\mathrm{C}|,|\mathrm{Mn}|,|\mathrm{Cr}|\})$, the equations (10) - (12) were obtained, which can be represented graphically using the $3^{\text {th }}$ dimensions. The correlation coefficients are $\mathrm{R}^{2}$ at $|\mathrm{C}|$ med $=0.8406, \mathrm{R}^{2}$ at $|\mathrm{Mn}|$ med $=0.9389$ and $\mathrm{R}^{2}$ at $|\mathrm{Cr}| \mathrm{med}=0.8649$.

$$
|\mathrm{HB}| \text { at }|\mathrm{C}|_{\text {med }}=\mathrm{b}_{1}|\mathrm{Mn}|^{2}+\mathrm{b}_{2}|\mathrm{Cr}|^{2}+\mathrm{b}_{3}|\mathrm{Mn}||\mathrm{Cr}|+\mathrm{b}_{4}|\mathrm{Mn}|+\mathrm{b}_{5}|\mathrm{Cr}|+\mathrm{b}_{6}
$$

where the correlation coefficient is $\mathrm{R}^{2}$ at $|\mathrm{C}|_{\text {med }}=0.8406$.

In the equation (10), the polynomial coefficients have the following values:

- Second-degree terms coefficients are: $b_{1}=616.5716$ and $b_{2}=-436.2808$;

— Product terms coefficient is: $b_{3}=309.2321$

- First-degree terms coefficients are: $b_{4}=-1289.6873$ and $b_{5}=-1266.5600$

- Constant term is: $\mathrm{b}_{6}=1683.3906$

$$
|\mathrm{HB}| \text { at }|\mathrm{Mn}|_{\text {med }}=\mathrm{c}_{1}|\mathrm{C}|^{2}+\mathrm{c}_{2}|\mathrm{Cr}|^{2}+\mathrm{c}_{3}|\mathrm{C}||\mathrm{Cr}|+\mathrm{c}_{4}|\mathrm{C}|+\mathrm{c}_{5}|\mathrm{Cr}|+\mathrm{c}_{6}
$$

where the correlation coefficient is $\mathrm{R}^{2}$ at $|\mathrm{Mn}|_{\text {med }}=0.9389$.

In the equation (11), the polynomial coefficients have the following values:

- Second-degree terms coefficients are: $c_{1}=416.3963$ and $c_{2}=371.8899$;

— Product terms coefficient is: $c_{3}=504.0918$

- First-degree terms coefficients are: $c_{4}=-1966.5005$ and $c_{5}=-1905.8528$

- Constant term is: $\mathrm{c}_{6}=3217.4702$

$$
|\mathrm{HB}| \text { at }|\mathrm{Cr}|_{\text {med }}=\mathrm{d}_{1}|\mathrm{C}|^{2}+\mathrm{d}_{2}|\mathrm{Mn}|^{2}+\mathrm{d}_{3}|\mathrm{C}||\mathrm{Mn}|+\mathrm{d}_{4}|\mathrm{C}|+\mathrm{d}_{5}|\mathrm{Mn}|+\mathrm{d}_{6}
$$

where the correlation coefficient is $\mathrm{R}^{2}$ at $|\mathrm{Cr}|_{\text {med }}=0.8649$.

In the equation (12), the polynomial coefficients have the following values:

- Second-degree terms coefficients are: $d_{1}=416.3963$ and $d_{2}=616.5716$;

- Product terms coefficient is: $\mathrm{d}_{3}=-573.5280$

- First-degree terms coefficients are: $d_{4}=-911.7162$ and $d_{5}=84.7159$

- Constant term is: $\mathrm{d}_{6}=1017.6826$ 


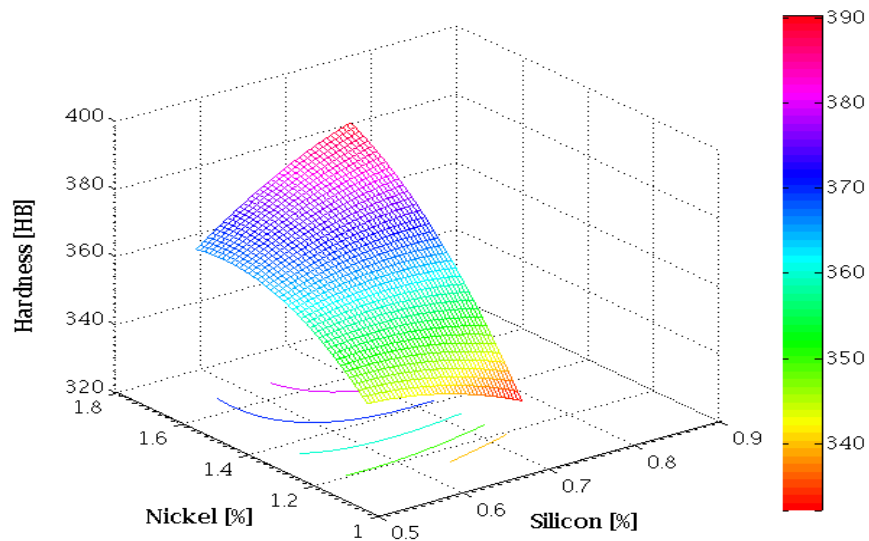

(a)

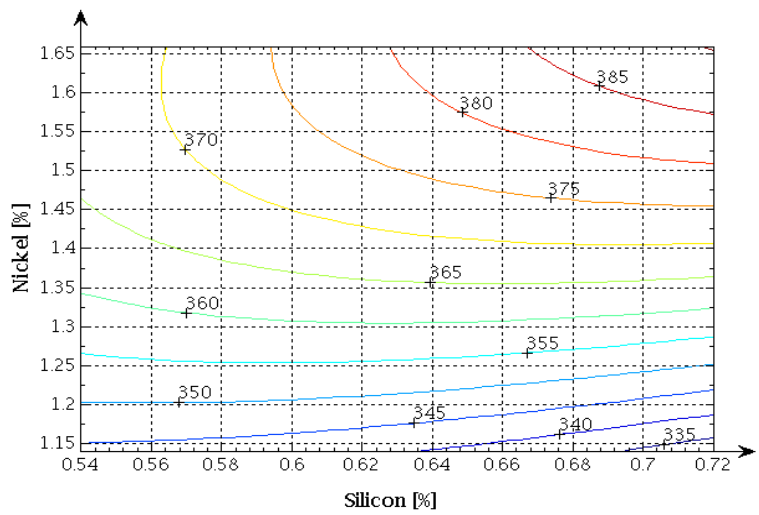

(b)



(c)

Figure 2

Correlation charts in case of series 1: $|\mathrm{HB}|=\mathrm{f}(|\mathrm{C}|,|\mathrm{Si}|,|\mathrm{Ni}|)$, when $|\mathrm{C}|=|\mathrm{C}|$ med. (a) the regression surface described by the industrial data; (b) the level curves of roll's hardness, in $|\mathrm{Si}|-|\mathrm{Ni}|$ coordinates;

(c) the hardness correlation chart, in $|\mathrm{Si}|-|\mathrm{Ni}|$ coordinates 




(a)

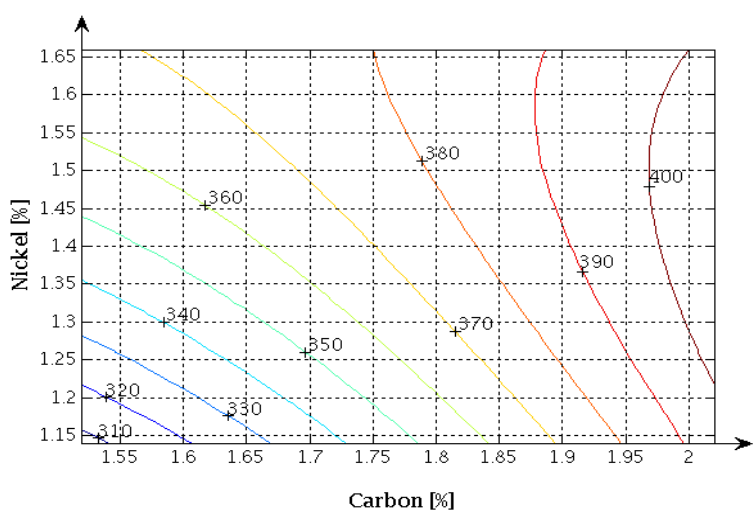

(b)

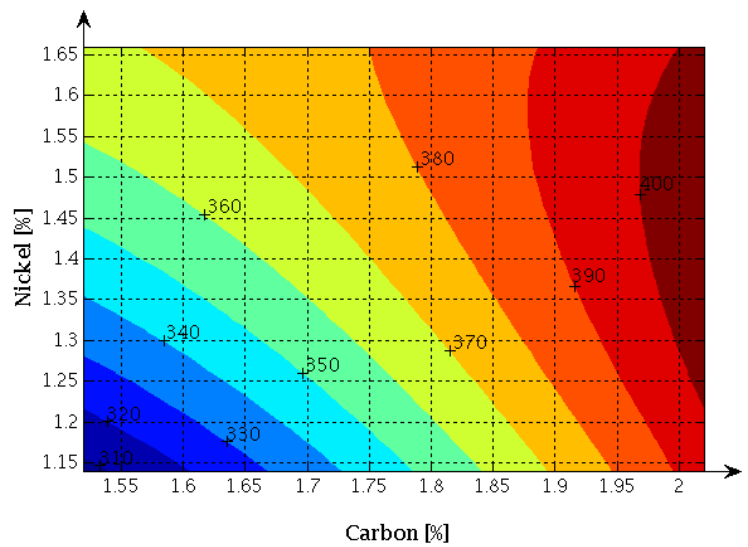

(c)

Figure 3

Correlation charts in case of series 1: $|\mathrm{HB}|=\mathrm{f}(|\mathrm{C}|,|\mathrm{Si}|,|\mathrm{Ni}|)$, when $|\mathrm{Si}|=|\mathrm{Si}|$ med. (a) the regression surface described by the industrial data; (b) the level curves of roll's hardness, in $|\mathrm{C}|-|\mathrm{Ni}|$ coordinates; (c) the hardness correlation chart, in $|\mathrm{C}|-|\mathrm{Ni}|$ coordinates 



(a)



(c)

Figure 4

Correlation charts in case of series 1: $|\mathrm{HB}|=\mathrm{f}(|\mathrm{C}|,|\mathrm{Si}|,|\mathrm{Ni}|)$, when $|\mathrm{Ni}|=|\mathrm{Ni}|$ med. (a) the regression surface described by the industrial data; (b) the level curves of roll's hardness, in $|\mathrm{C}|-|\mathrm{Si}|$ coordinates; (c) the hardness correlation chart, in $|\mathrm{C}|-|\mathrm{Si}|$ coordinates 


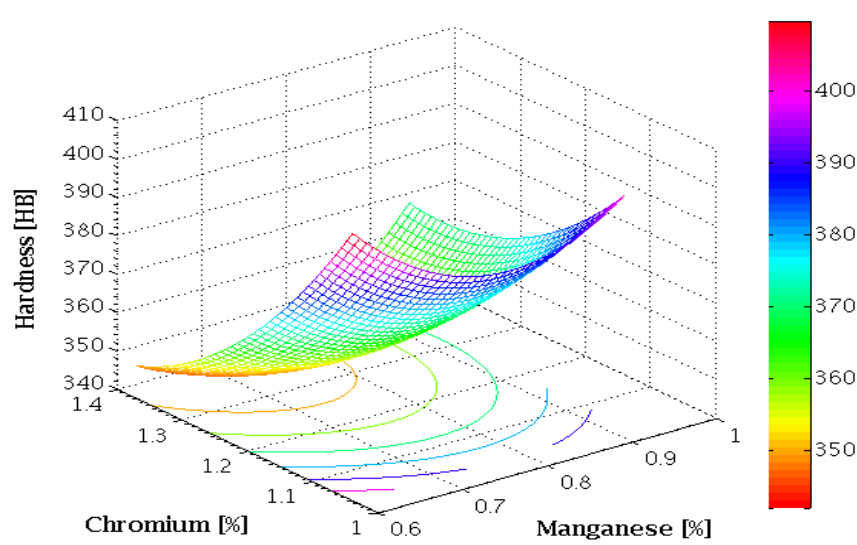

(a)

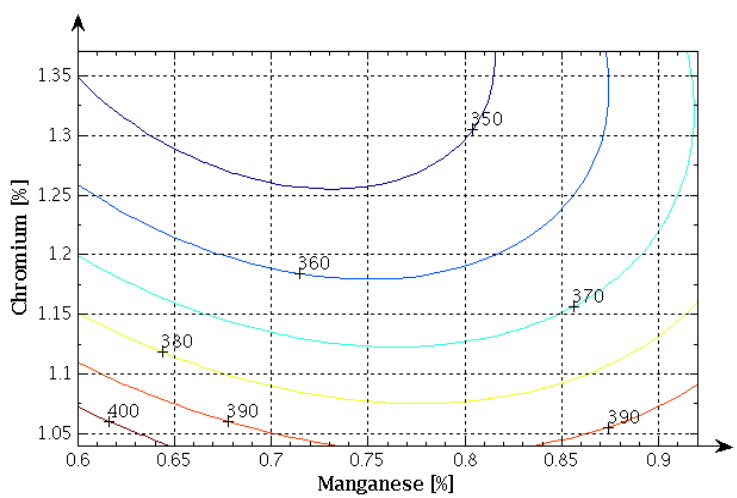

(b)

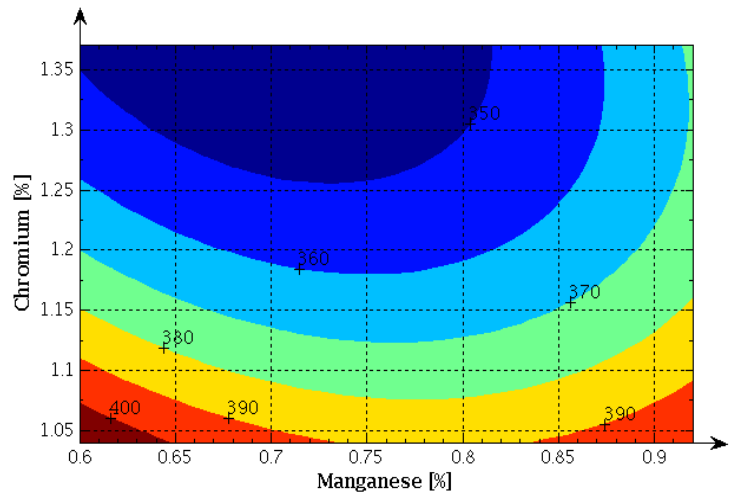

(c)

Figure 5

Correlation charts in case of series 2: $|\mathrm{HB}|=\mathrm{f}(|\mathrm{C}|,|\mathrm{Mn}|,|\mathrm{Cr}|)$, when $|\mathrm{C}|=|\mathrm{C}| \mathrm{med}$. (a) the regression surface described by the industrial data; (b) the level curves of roll's hardness, in $|\mathrm{Cr}|-|\mathrm{Mn}|$ coordinates; (c) the hardness correlation chart, in $|\mathrm{Cr}|-|\mathrm{Mn}|$ coordinates 


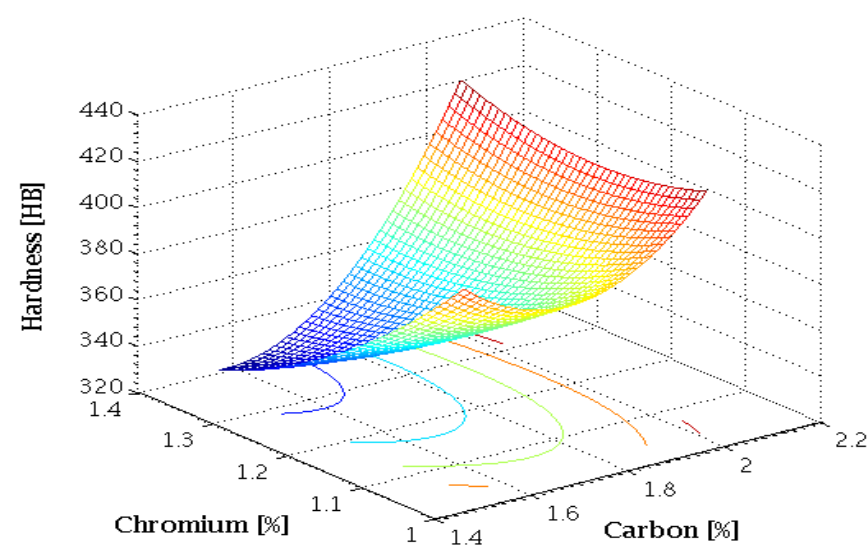

(a)

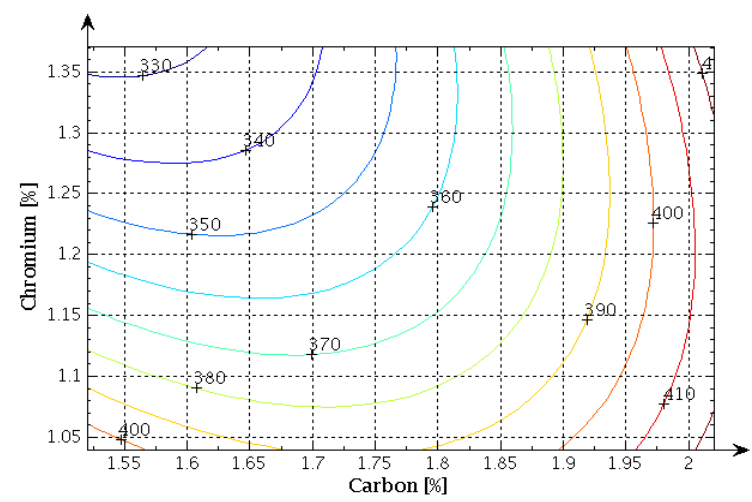

(b)

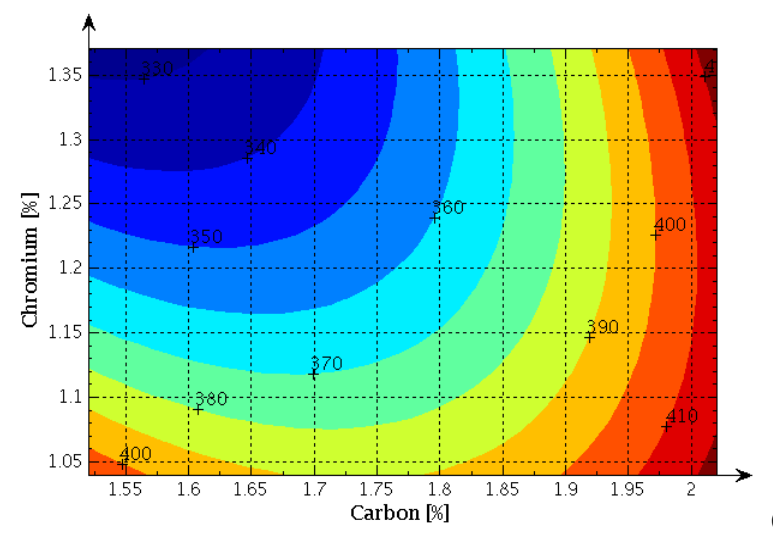

(c)

Figure 6

Correlation charts in case of series 2: $|\mathrm{HB}|=\mathrm{f}(|\mathrm{C}|,|\mathrm{Mn}|,|\mathrm{Cr}|)$, when $|\mathrm{Mn}|=|\mathrm{Mn}|$ med. (a) the regression surface described by the industrial data; (b) the level curves of roll's hardness, in $|\mathrm{Cr}|-|\mathrm{C}|$ coordinates; (c) the hardness correlation chart, in $|\mathrm{Cr}|-|\mathrm{C}|$ coordinates 


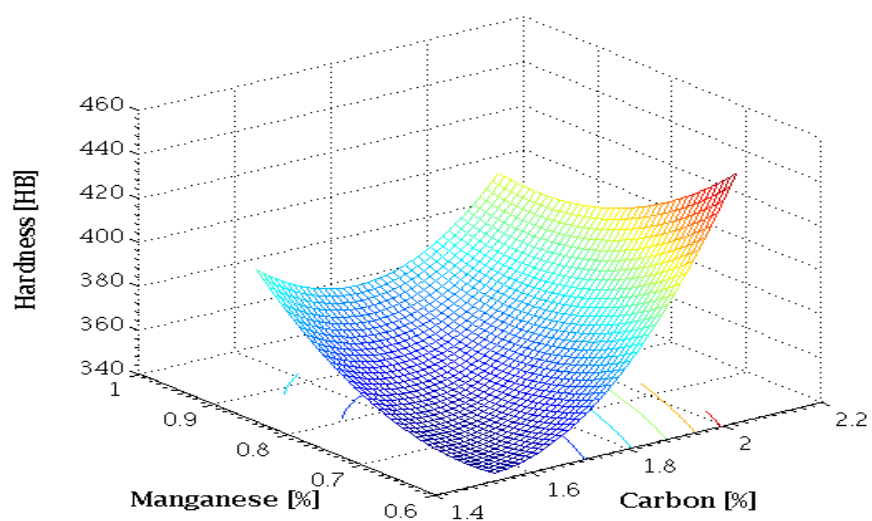

(a)

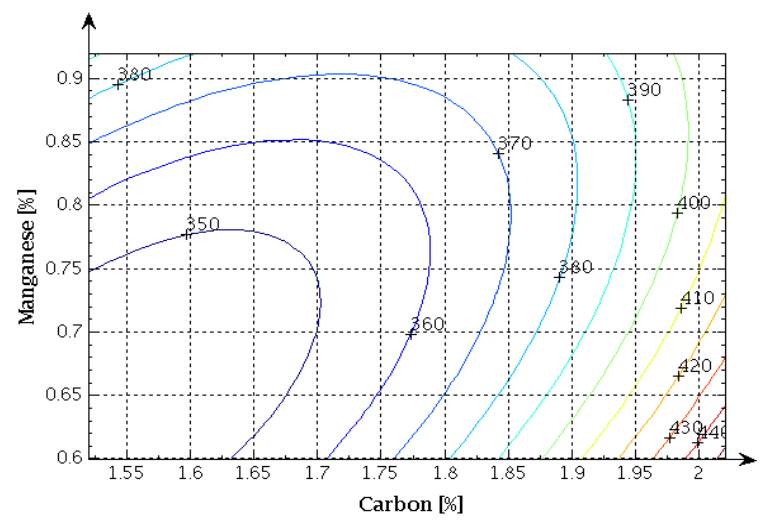

(b)

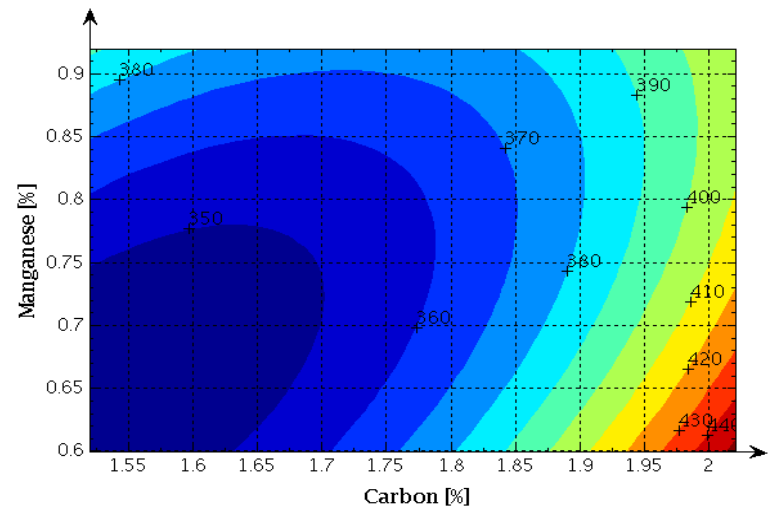

(c)

Figure 7

Correlation charts in case of series 2: $|\mathrm{HB}|=\mathrm{f}(|\mathrm{C}|,|\mathrm{Mn}|,|\mathrm{Cr}|)$, when $|\mathrm{Cr}|=|\mathrm{Cr}|$ med. (a) the regression surface described by the industrial data; (b) the level curves of roll's hardness, in $|\mathrm{Mn}|-|\mathrm{C}|$ coordinates; (c) the hardness correlation chart, in $|\mathrm{Mn}|-|\mathrm{C}|$ coordinates 


\section{Graphical Addenda}

The $3^{\text {th }}$ dimensional regression surfaces, described by the governing equations (4), (6) and (8), respectively by the equations (10)-(12), are represented graphically. In this sense, correlation of twos elements with the hardness can be analyzed, keeping the third element at its average value. Therefore, the proper hardness can be obtained in between the requested limits.

The regression surfaces described by the industrial data, the level curves and the hardness correlation charts are presented in the Figures 2-7 (a)-(c).

\section{Discussion}

Regarding the melting and alloying process of the Adamite hyper-eutectoid steel rolls manufacturing, we have the following technological remarks:

- One of the basic factors that determine the structure of the Adamite type rolls is the chemical composition of the cast hyper-eutectoid steel, basic elements like Carbon $|\mathrm{C}|$, Manganese $|\mathrm{Mn}|$ and Silicon $|\mathrm{Si}|$ and also alloying components like, Nickel $|\mathrm{Ni}|$ and Chrome $|\mathrm{Cr}|$

- Alloying combinations of different element like Chrome $|\mathrm{Cr}|$ and Nickel $|\mathrm{Ni}|$ are normally used to achieve the desired physical and mechanical properties

- The main chemical composition must be correlated with further addition of the main alloying elements (Chrome $|\mathrm{Cr}|$ and Nickel $|\mathrm{Ni}|)$, respecting the adequate ratio between Silicon $|\mathrm{Si}|$ and Nickel $|\mathrm{Ni}|$, as graphitizing forming elements, or between Manganese $|\mathrm{Mn}|$ and Chrome $|\mathrm{Cr}|$, as carbide forming elements in these kind of high carbon steels

- All these correlations must be made besides a proper ratio of Carbon $|\mathrm{C}|$, Silicon $|\mathrm{Si}|$ and Nickel $|\mathrm{Ni}|$, respectively Carbon $|\mathrm{C}|$, Manganese $|\mathrm{Mn}|$ and Chrome $|\mathrm{Cr}|$, having in view the behaviour of this elements, using the triple correlations

- A proper addition of the Manganese $|\mathrm{Mn}|$ and Silicon $|\mathrm{Si}|$ contents is provided by the basic metallic charges and from the Ferro-alloys (Fe-Mn, $\mathrm{Fe}-\mathrm{Si}$ and $\mathrm{Si}-$ $\mathrm{Mn})$ used for corrections in the melting process

- A proper addition of the Chrome $|\mathrm{Cr}|$ and Nickel $|\mathrm{Ni}|$ contents is provided by the metallic charges and from the Ferro-alloys ( $\mathrm{Fe}-\mathrm{Cr}$ and $\mathrm{Fe}-\mathrm{Ni})$ used in the alloying process 
Regarding the statistical modeling by the multiple regression analysis, in order to understand the relationships between the proper hardness and the hyper-eutectoid steel roll's chemical compositions and their relevance to the problem being studied, we have the following remarks:

- The used multivariate analysis, as a predictive analysis, was based on the statistical principle of multivariate statistics, based on the association between two or more independent variables and a single continuous dependent variable, which involves observation of the hardness variations of the Adamite hypereutectoid steel roll's chemical compositions

- Multiple regression was used in scope to predict the value of a variable based on the value of two or more other variables. In the used statistical modelling, the regression analysis was used for estimating the relationships among the proper hardness and the graphitizing forming elements, on one side, and the proper hardness and the carbide forming elements, on the other side

- This method should be applicable to many situations in rolls manufacturing (including in melting and alloying stages) in which multiple factors interact to determine a categorical dependent mechanical property, provided that the sample sizes are sufficient. This method explores usually large amounts of data in search of systematic relationships between the specific variables, in scope of prediction which will be applied in the future manufacturing processes. In this sense, we analysed a large lot of Adamite rolls (60 rolls)

- This multivariate statistical method affords the opportunity to analyse many variables together - i.e. the Adamite hyper-eutectoid steel roll's chemical compositions, in order to understand how they function as a metallurgical system with cumulative effects, for obtaining an proper mechanical properties - i.e. the hardness

Regarding the regression analysis, based on the industrial data, related to the determination of the multicomponent equations and the correlation charts, we have the following comments:

- The hardness variations, described by Adamite steel roll's chemical composition's graphitizing forming elements (Silicon $|\mathrm{Si}|$ and Nickel $|\mathrm{Ni}|$ ), are presented in Figures 2-4 (a), determined by Matlab, using a polynomial equations type, presented in equations (4), (6) and (8), with standard deviation $\mathrm{R}^{2}$ between $0.8108-0.9219$

- The hardness variations, described by Adamite steel roll's chemical composition's carbide forming elements (Manganese $|\mathrm{Mn}|$ and Chrome $|\mathrm{Cr}|$ ), are presented in Figures 5-7 (a), determined by Matlab, using a polynomial equations type, presented in equations (10)-(12), with standard deviation $\mathrm{R}^{2}$ between $0.8406-0.9389$ 
- In both cases (series 1 and series 2), the higher values of the standard deviation $\mathrm{R}^{2}$ shows then there is a major relationship between the variables, having in view that in multiple regression, $\mathrm{R}^{2}$ can assuming values between 0 and 1 . To interpret the direction of the relationship between variables, we look at the signs (plus or minus) of the regression coefficients (the second-degree terms coefficients, the first-degree terms coefficients, the product terms coefficients and the constant terms), revealed in equations (4), (6) and (8), respectively in equations (10)-(12)

- Having in view the $4^{\text {th }}$ dimensional regression surfaces, described by the governing equations (2) and (9), which have standard deviation $\mathrm{R}^{2}=0.9240$, respectively $R^{2}=0.9508$, we've got an extra confirmation that there is a major relationship between the analyzed variables. Therefore, both graphitizing forming elements (Silicon $|\mathrm{Si}|$ and Nickel $|\mathrm{Ni}|$ ) and carbide forming elements (Manganese $|\mathrm{Mn}|$ and Chrome $|\mathrm{Cr}|$ ) have a major influence upon the roll's hardness, even from the melting and alloying processing stages;

- The technological domains area of proper hardness, described by the graphitizing forming elements and by the carbide forming elements are presented in Figures 2-4 (b)-(c), respectively in Figures 5-7 (b)-(c). The relationships that determine the technological areas are useful because they can indicate a predictive relationship that can be exploited in practice.

\section{Concluding Remarks}

Based on the results obtained in the performed statistical research, the Author has concluded that realization of the proper balance between the carbide forming elements and the graphitizing forming elements of the Adamite roll's chemical composition is an efficient way to assure the mechanical characteristics, especially the hardness. In fact, the mathematical modelling based on industrial data establishes a statistical approach for determination of melting and alloying process parameters of hyper-eutectoid steels destined to the Adamite type rolls manufacturing, which will assure a the proper hardness.

This statistical research supports the techniques of alloy analysis, intended for cast rolls. It is important to mention that the implementation of these results in the rolls foundry practice also provides guarantees on quality assurance of the cast rolls, having in view that the hardness assurance, represents the control of the entire roll manufacturing process.

\section{Acknowledgement}

At the fundament of this statistical research upon the Adamite hyper-eutectoid steel rolls are several scientific works in which the author is involved in the last 20 years, through his experience gained as an engineer in a well-known factory for its cast rolls production. The research includes the own studies, analyses, experiments and research, [1-8], regarding the quality improvement of the main rolls used in the steel rolling. 


\section{References}

[1] I. Kiss, Rolling rolls - Approaches of quality in the multidisciplinary research, Mirton publishing House, Timisoara, 2008

[2] I. Kiss, St. Maksay, Graphical addenda in the technological area of the nodular iron cast rolls production, Acta Polytechnica Hungarica, 5/4 (2008), pp. 15-27

[3] I. Kiss, Research upon the quality assurance of the rolling-mill rolls and the variation boundaries of the chemical composition, Revista de Metalurgia, 44/4 (2008), pp. 335-342

[4] I. Kiss, V G Cioată and V Alexa Increasing the rolling-mill rolls quality in some multidisciplinary research, Acta Technica Corviniensis - Bulletin of Engineering III/2 (2010), pp. 31-36

[5] I. Kiss, V G Cioată, V Alexa and S A Ratiu, Technological behaviour and interpretations in some multidisciplinary approaches, Annals of F.E.H. International Journal of Engineering IX/4 (2011), pp. 203-206

[6] I. Kiss, Investigations upon the indefinite rolls quality assurance in multiple regression analysis, Revista de Metalurgia, 48/2 (2012), pp. 85-96

[7] I. Kiss, V Alexa, S. Serban, M, Rackov and M. Čavić, Statistical research using the multiple regression analysis in areas of the cast hyper-eutectoid steel rolls manufacturing, IOP Conference Series: Materials Science and Engineering, 294/1 (2018) pp. 1-9

[8] I. Kiss, Cast Iron Rolls - An overview on the proper hardness assured by the manufacturing process, Technical Journal 13/2 (2019), pp. 92-99

[9] A. Brodziak, Z. Stradomski and A. Pirek, The influence of microstructure on the mechanical properties of metallurgical rolls made of G200CrMoNi4-3-3 cast steel, Archives of Foundry Engineering, 9/3 (2009), pp. 21-24

[10] Z. Stradomski, A. Pirek and S. Stachura, Studying possibilities to improve the functional properties of metallurgical rolls, 8/1 (2008), pp. 313-316

[11] L. B. Medovar and G. K. Vercen, Production and application of rolls: Some trends and prospects. Russian Metallurgy (Metally), 8 (2008), pp. 744-746

[12] K. C. Hwang, S. Lee, H. C. Lee, Effects of alloying elements on microstructure and fracture properties of cast high speed steel rolls: Part I: Microstructural analysis, Materials Science and Engineering: A, 254/1-2, (1998), pp. 282-295

[13] A. I. Belyaev, A. V. Terentev and S. V. Mikhaylitsyn, Special features of surfacing of hypereutectoid steels, Journal Welding International, 30/6 (2016), pp. 467-471 
[14] H. Noguchi, H. Hiraoka, Y. Watanabe and Y. Sayama, Hardness and wear resistance of adamite for work rolls in hot rolling mill, Transactions of the Iron and Steel Institute of Japan, 28/6, (1988), pp. 478-484

[15] J. Krawczyk, E. Rozniata and J. Pacyna, The influence of hyper-eutectoid cementite morphology upon fracture toughness of Chromium-NickelMolybdenum cast steel of ledeburite class, Journal of Materials Processing Technology, 162-163 (2005), pp. 336-341

[16] J. Krawczyk and S. Parzych, Microstructure formation and properties of abrasion resistant cast steel, Archives of Foundry Engineering, 10/1 (2010), pp. 295-300

[17] S. I. Rudyuk, I. V. Mikhailova and Y. S. Tomenko, The effect of alloying and heat treatment on the properties of hyper-eutectoid steels for rollingmill rolls, Metal Science and Heat Treatment, 32/4 (1990), pp. 261-264

[18] I. V. Mikhailova, S. I. Rudyuk and A. I. Savon, Effect of alloying elements on the structure of cast hyper-eutectoid steels after heat treatment, Metal Science and Heat Treatment, 29/8 (1987), pp. 634-637

[19] I. Ilca, I. Kiss, V. Alexa, S. A. Raţiu, Optimisation of the thermal treatment technologies for the cast hiper-eutectoid steel rolls, Annals of Faculty Engineering Hunedoara - International Journal of Engineering, XIV, 3 (2016), pp. 201-206

[20] E. Rozniata and J. Pacyna, Hyper-eutectoid cementite morphology and mechanical properties of $\mathrm{Cr}-\mathrm{Ni}-\mathrm{Mo}$ cast steel, Journal of Achievements in Materials and Manufacturing Engineering, 17/1-2 (2006), pp. 145-148

[21] A. M. Elwazri and S. Yue, Effect of Pearlite Structure on the Mechanical Properties of Microalloyed Hyper-eutectoid Steels, Materials Science Forum, 500-501 (2005), pp. 737-744

[22] A. M. Elwazri, P. Wanjara and S. Yue. The effect of microstructural characteristics of pearlite on the mechanical properties of hypereutectoid steel, Materials Science and Engineering: A, 404/1-2 (2005), pp. 91-98

[23] E. M. Taleff, J. J. Lewandowski and B. Pourladian, Microstructure-property relationships in pearlitic eutectoid and hyper-eutectoid carbon steels, Jom, 54, 7 (2002), pp. 25-30

[24] M. Ueda, K. Uchino and A. Kobayashi, Effects of carbon content on wear property in pearlitic steels, Wear, 253/1-2 (2002), pp. 107-113 